DOI 10.18551/rjoas.2021-09.12

\title{
ASSESSMENT OF EXTENSION COMMUNICATION CHANNELS AMONG AGROFORESTRY FARMERS IN EKITI STATE, NIGERIA
}

\author{
Suleiman R.A. \\ Trial Afforestation Research Station, Afaka, Kaduna, Kaduna State, Nigeria \& \\ Forestry Research Institute of Nigeria, Ibadan, Oyo State, Nigeria
}

Ikani E. I., Mamma S.

Department of Agricultural Extension and Rural Development, Ahmadu Bello University, Zaria, Kaduna State, Nigeria

\author{
Ariyo O.C. \\ Department of Entrepreneurship and Innovative Agriculture, Federal College of Forestry \\ Mechanization, Afaka, Kaduna \& Forestry Research Institute of Nigeria, Ibadan, Oyo State, \\ Nigeria \\ Oladele O.N. \\ Trial Afforestation Research Station, Afaka, Kaduna, Kaduna State, Nigeria \& Forestry \\ Research Institute of Nigeria, Ibadan, Oyo State, Nigeria \\ Adelani O.D. \\ Department of Forestry Technology, Federal College of Forestry Mechanization, Afaka, \\ Kaduna \& Forestry Research Institute of Nigeria, Ibadan, Oyo State, Nigeria \\ *E-mail: ask4ariyo@yahoo.com
ORCID: 0000-0001-8512-9433
}

\begin{abstract}
Communication channels are pathways through which information or messages are transmitted to an audience or receiver. The focus of this study was to assess extension communication channels among agro-forestry farmers in Ekiti State, Nigeria. Primary data were collected from 267 respondents using structured questionnaire. The data were analysed with descriptive statistics and 5-points likert scale. The result showed that $(44.57 \%)$ of the farmers are within productive age bracket (21-40 years) with an average age of 38 years. Majorities (67.4\%) of the farmers are male and $73.4 \%$ married. The result showed that the majority of the respondents are male $(67.4 \%)$ with mean age of 38 years. They are married (73.4\%) with average household size of 5, average farm size 2.8 ha and average farming experience of 11 years respectively. The result further showed that radio $(79.78 \%)$ and television $(70.79 \%)$ were rated high by the famers among the channel of communication used in the dissemination of agro-forestry technology. Also, radio $(81.65 \%)$ and television $(73.03 \%)$ are the major source of information to agro-forestry farmers. Tree and shrubs on pasture system $\left(\mathcal{H}^{-}=3.91 ; \mathrm{SD}=1.06\right)$ and integrated production system $(\mathcal{H}=3.90 ; \mathrm{SD}=1.03)$ are the most aware agro-forestry technologies by the farmers. Group discussion $(79.78 \%)$ and visit $(70.79 \%)$ were the most preferred extension communication channels. Inadequate extension agent (80.15\%), incompetency of extension agents $(62.55 \%)$ and respondent's poor attendance at meeting $(52.43 \%)$ are the major constraint to effective extension communication channels. The study recommends the use of group discussion and visit as the most appropriate communication channels to the agro-forestry farmers in the study area. Also, more trained extension agents should be made available to farmers for effective and efficient agro-forestry technologies delivery.
\end{abstract}

\section{KEY WORDS}

Communication channel, agroforestry technology, extension agent, sources of information. 
Communication as defined by Rogers (2003) is the process by which participants create and share information/knowledge with each other with the aim of reaching a mutual understanding while communication channels are pathways through which information or message transmitted to an audience or receiver (Ogunremi, 2013). They are methods or vehicles by which information is transferred or received (Ivan et al., 2012). Communication channels defined by Age et al., (2012), as the means through which messages travel from the source to the receiver and vice versa. Some of the communication channels used in disseminating agricultural information include personal contacts; radio broadcasts; publications; field days; agricultural shows; demonstrations etc. These channels can be grouped into five categories. Physical channels which involve direct contact, this may include seminars, exhibitions. Non-physical channels, which include television, radio, phone calls, newspapers and other print media channels. Technical channels, this could be either physical or non-physical. Human discipline channel, for example, dress put on professionals such as farmers to predict the profession and last but not least, token of communication channels, which are channels in between physicals and non-physicals, this may include signals and gestures and other symbols (Age et al., 2012).

According to Ivan et al., (2012) channels can be broadly grouped into two types; disseminative and communicative. Dissemination is distinct from communication as the former entails the uni-directional (or one-way) flow of messages, information or knowledge from source to the recipient. Robinson et al. (2005) describe dissemination as a one-way active transfer process from resource to user groups. Conversely, communication is the multi-directional (or two-way) flow of information/knowledge between source and recipient and thus necessitates feedback.

Traditionally, it is assumed that good innovations sell themselves, but experience has shown that they do not (Olowu et al., 2001; Elijah, 2010). Therefore, existing technologies or recommendations need to be disseminated to the farming audience. Extension agents carefully adapt communication strategies and channels to each local situation (Nwaiwu et al., 2018). Effective communication between change agents and researchers is essential for increasing agricultural production through the use of improved technologies.

Agricultural extension by its nature has an important role in promoting the adoption of new technologies and innovations (Jamilah et al., 2010). Agricultural extension brings about changes through education and communication in farmers attitude, knowledge and skills. The role of agricultural extension involves dissemination of information; building capacity of farmers through the use of a variety of communication methods and help farmers make informed decisions (Sinkaiye, 2005).

Poor communication as a result of uncoordinated channels of information delivery to farmers has been a major deterrence to information flow between researchers and farmers (Rees et al., 2000). Utilizing preferred information channels for implementing an activity or sharing information about a new technology enhances community participation and adoption. For disseminating information about an innovation, identifying channels from sources to users is recommended; while for facilitating the generation of an innovation it is necessary to identify both channels from sources to users and from users to sources.

Effective extension communication channels must constantly assess the impact of their information delivery system to farmers' and design communication strategies that are effective in informing farmers' in a timely, clear and effective manner to encourage awareness, acceptance and use of innovations. Very few studies have addressed the use of communication channels in disseminating agro-forestry technologies to farmers and this creates a knowledge gap. Information about which channels are preferred by agro-forestry farmers is also limited. Besides, there is a paucity of literature on the assessment of extension communication channels among agro-forestry farmers especially in the study area. It was against this backdrop the research was designed to achieve the following objectives:

- describe the socio-economic characteristics of agro forestry farmers in the study area;

- identify the communication channels used in the dissemination of agro-forestry technologies; 
- Identify the sources of information to agro-forestry famers;

- assess the level of awareness of various agro-forestry technologies among agroforestry farmers;

- identify the most preferred extension communication channels by the agro-forestry farmers in the study area;

- identify the constraints to effective extension communication channels in disseminating agro forestry technologies to farmers in the study area.

\section{METHODS OF RESEARCH}

The study was conducted in Ekiti State (Figure 1). The state is geographically located in the South West of Nigeria; it is an agrarian state, having 16 Local Government Areas. It is located between longitudes $40^{\circ} 51^{\prime}$ and $50^{\circ} 151^{\prime}$ East of the Greenwich meridian and latitudes $70^{\circ} 151^{\prime}$ and $80^{\circ} 51^{\prime}$ North of the equator. It has a total land area of $5887.89 \mathrm{sq} \mathrm{km}$. The population is $8,159,476$ people as at 2006 with a projected growth rate of 3.2 NPC, (2006). The state is further divided into three political (senatorial) zone viz: Ekiti north; Ekiti south; and Ekiti Central (Dahunsi, 2012). Among the different occupations agriculture is the main occupation and the most important source of employment as it employs over $75 \%$ of the people. They produce crops such as cassava, yam, maize, rice, kola nut, cocoa among other farm products. Many other residents of the State are either civil servants or traders. The State also has abundant forest resources, notably timber due to the favourable climatic condition in the areas. Ekiti and Ondo State according to (Faleyimu et al., 2013) have 37 forest reserves covering about 305, 541 hectares. The people of Ekiti are Yoruba speaking and have a rich culture comprising of many aspects including music, dance, mode of dressing, cooking, respect for elders etc. Among the Yoruba people of South Western Nigeria, the people of Ekiti State are known for their high educational attainment. The major religion practiced in Ekiti State is Christianity followed by Islam and the African Traditional Religion.

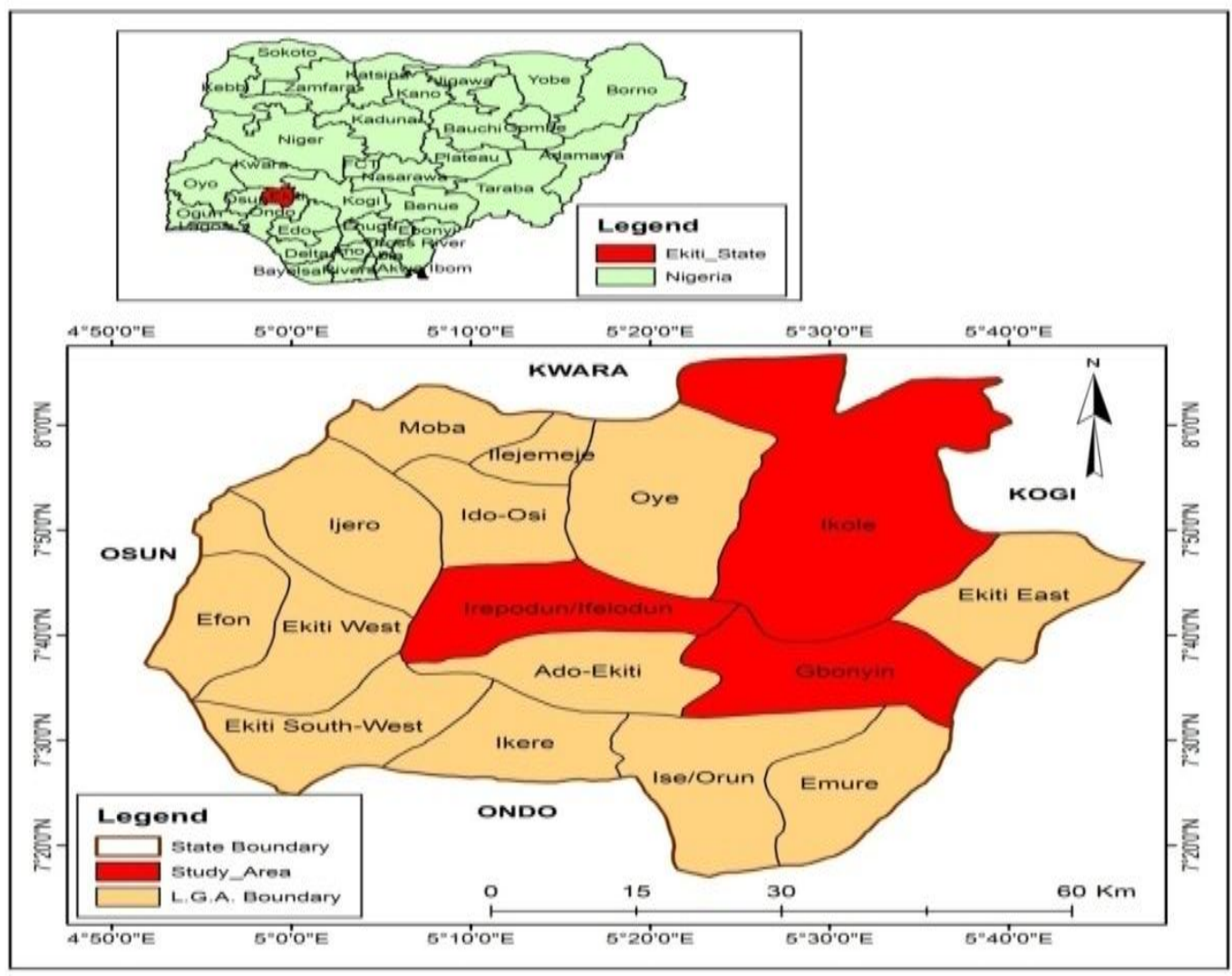

Figure 1 - Map of Nigeria showing Ekiti State and the study area 
The study was carried out in three agro-ecological zones of Ekiti State namely: Ekiti North with six (6) LGAs, Ekiti South and Ekiti Central with five LGAs each, making a total number of sixteen (16) LGAs in Ekiti State. A multi-stage sampling procedure was used in the selection of respondents for data collection. In the first stage, one Local Government Area was purposively selected from each agro-ecological zone based on the extent of agro forestry practices in the area. In the second stage, five (5) villages were selected randomly in each Local Government Area making a total of fifteen (15) communities. Finally, a random selection was used to select thirty-five percent of the total population of agro forestry farmers in each selected village making a total of 265 out of 758 .

Primary data were collected through the administration of structured questionnaire to 265 agro-forestry farmers. The questionnaire was prepared in line with the objectives of the study and subjected to validity and reliability test. The questionnaire consists of open and closed ended questions and administered to the respondents by personal interview.

The data collected were analyzed with descriptive statistics such as frequency table, mean, percentages and Likert scale. The 5- point Likert scale was used to access the level of awareness of various channels used to disseminate agro-forestry technologies among agroforestry famers in the study area. The rating are (Highly aware $=5$, aware $=4$, undecided/neutral $=3$, unaware $=2$ and highly unaware $=1$ ). Weight of $5,4,3,2$ and 1 was assigned respectively. For each indicator a weighted mean was obtained. follows:

Based on this perception analysis, the mean(s) for all indicators was categorized as

- If the mean score fell between 1.00 to 1.49 is classified as highly unaware;

- If the mean score fell between 1.50 to 2.49 is classified as unaware;

- If the mean score fell between2.50 to 3.49 is classified as Undecided/Neutral;

- If the mean score fell between 3.50 to 4.49 is classified as aware;

- If the mean score fell within 4.50 to 5.00 is classified as highly aware.

\section{RESULTS AND DISCUSSION}

The socio-economic characteristics of the agro-forestry farmers considered in this study are age, gender, marital status, farming experience, household size, farm size, extension contact and cooperative membership.

Table 1 - Age Distribution of Agro-forestry Farmers

\begin{tabular}{lll}
\hline Age (years) & Frequency & Percentage \\
\hline$\leq 20$ & 30 & 11.24 \\
$21-30$ & 30 & 11.24 \\
$31-40$ & 89 & 33.33 \\
$41-50$ & 59 & 22.10 \\
$51-60$ & 53 & 19.85 \\
$61-70$ & 6 & 2.25 \\
Total & 267 & 100 \\
Mean & 38 & \\
Min. & 16 & \\
Max. & 64 & \\
SD & 12.09 & \\
\hline
\end{tabular}

The age distribution of agro-forestry famers on Table 1 showed the mean age of 38 years with minimum and maximum age of 16 and 64 years respectively. The table further showed that the highest number of respondents (44.57\%) was in the productive age bracket (21- 40 years). This shows that the majority of the farmers falls within economically active age group and can stand the demands for agroforestry technology adoption. This finding is in line with Ariyo et al. (2013) who reported that most of the respondents (83.33\%) fell between 20 and 60 years of age with a mean age of 38 years. Minot and Ngigi, (2006) explained that age may be associated with accumulation of skills, more experience and accumulation of assets thereby allowing the participants to increase their productivity. There were a number 
of ageing respondents between the ages of 61 and 70 constituting 2.25\% engaged in agroforestry activities. The implication of this finding is that governments should institute policies that would attract young people into the agricultural sector since their technology adoption behaviours are crucial to improvement in agricultural productivity.

The result in Figure 1 showed the distribution of agroforestry farmers based on gender. The majority of the farmers $(67.4 \%)$ were male. This result is largely skewed towards male farmers. However, for effective transfer and adoption of technologies for increase food production in the rural areas, gender has become the most important determinant of the distribution of rights, resources and responsibilities among individuals, families and communities. This finding is in line with Ewuola et al. (2010) who worked on assessment of extension media use among youth farmers in Oyo and Ondo States, Nigeria, showed that majority $(62.5 \%)$ of the respondents were males, this may be as a result of cumbersome masculine nature of farming activities. Ariyo et al. (2013) on assessment of the role of mass media in the dissemination of agricultural technologies among farmers in Kaduna state revealed that $59.3 \%$ of the respondents were male while $40.7 \%$ were female.

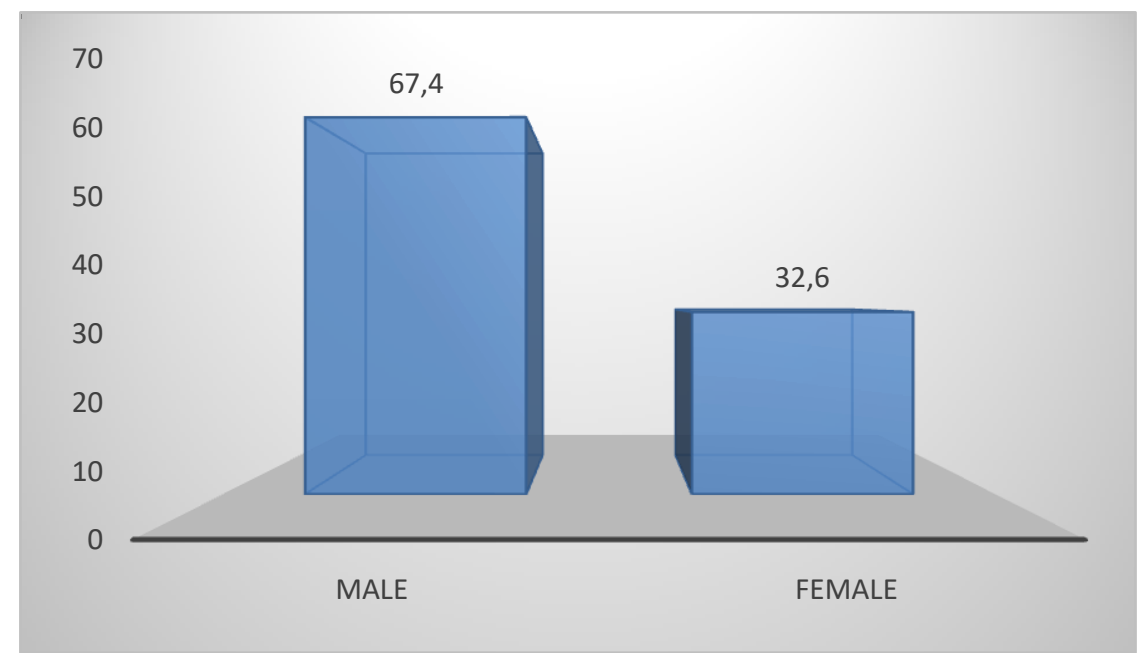

Figure 1 - Gender distribution of agro-forestry farmers

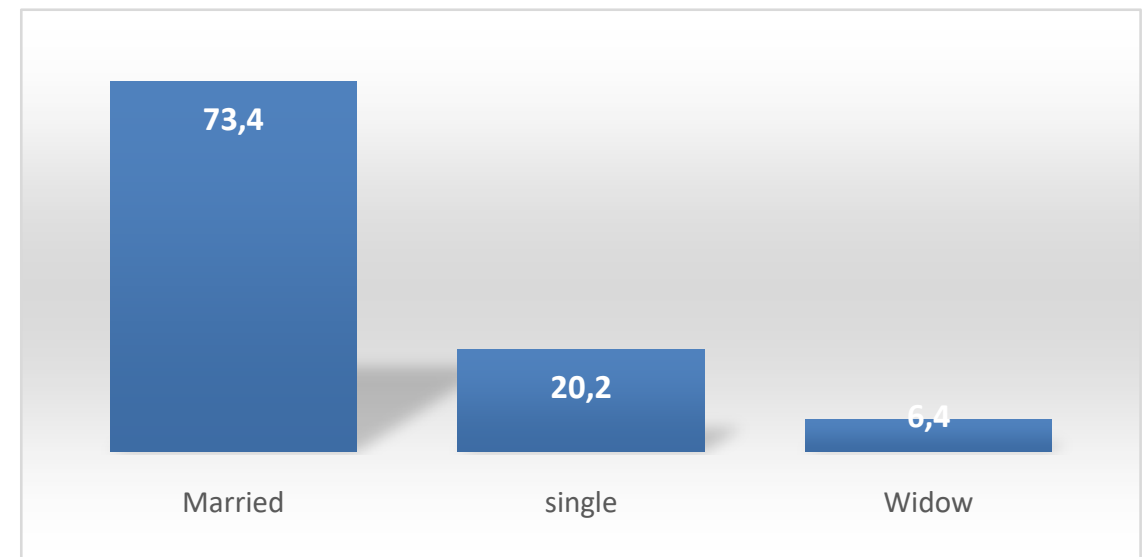

Figure 2 - Marital status distribution of agro-forestry farmers

The marital status of agro-forestry farmers on Figure 2 showed that $73.4 \%$ of the farmers are married, $20.2 \%$ are single and $6.4 \%$ are widowed. Marital status may influence the size of households as married farmers may have larger household sizes which may encourage them to participate in agroforestry adoption in order to raise their income and level of living. The significance of marital status on agricultural production and livelihood activities can be explained in terms of the supply of agricultural family labour. It is expected that family labour would be more available where the household heads are married ceteris 
paribus. This finding is in line with Bello (2016) who worked on evaluation of factors influencing the utilization of extension services provided by Adamawa Agricultural Development and Investment Limited to Maize farmers in Adamawa State, Nigeria, revealed that high proportions (75.8\%) of the respondents were married, $13.0 \%$ widowed, $7.6 \%$ single, and $3.6 \%$ divorced. According to Adamu (2005) who reported that about $90 \%$ of Nigerian populations are engaged in agricultural production processes of various types regardless of their marital status. However, it could be deduced that since majority of the respondents were married, it is expected that they will source for agricultural technologies through the mass media to increase their productivity and enhance their income.

The educational status distribution of agro-forestry farmers on Figure 3 showed that majority $(75.7 \%)$ of the farmers had tertiary education, $20.2 \%$ had secondary school education while only $2.2 \%$ and $1.9 \%$ had non-formal and primary education respectively. The overall educational status of the farmers in this study indicated that most $(97.8 \%)$ of the farmers were "fairly" educated. The implication of this is the greater potential of adoption of innovations and easy access of information. Furthermore, more educated farmers are typically assumed to be better able to process information and search for appropriate technologies to alleviate their production constraints. The belief is that education gives farmers the ability to perceive, interpret and respond to new information much faster than their counterparts without education. This finding is in line with Lawal and Idega (2004) who observed that the level of education of farmers greatly determines the strategies they may use to relate to extension officers and their services. This result is also in consonance with documentation of Ajayi and Gunn (2009) who reported that $43 \%$ of respondents had up to secondary education and the rest had only Quranic education and this influenced the adoption rate of agroforestry technology.

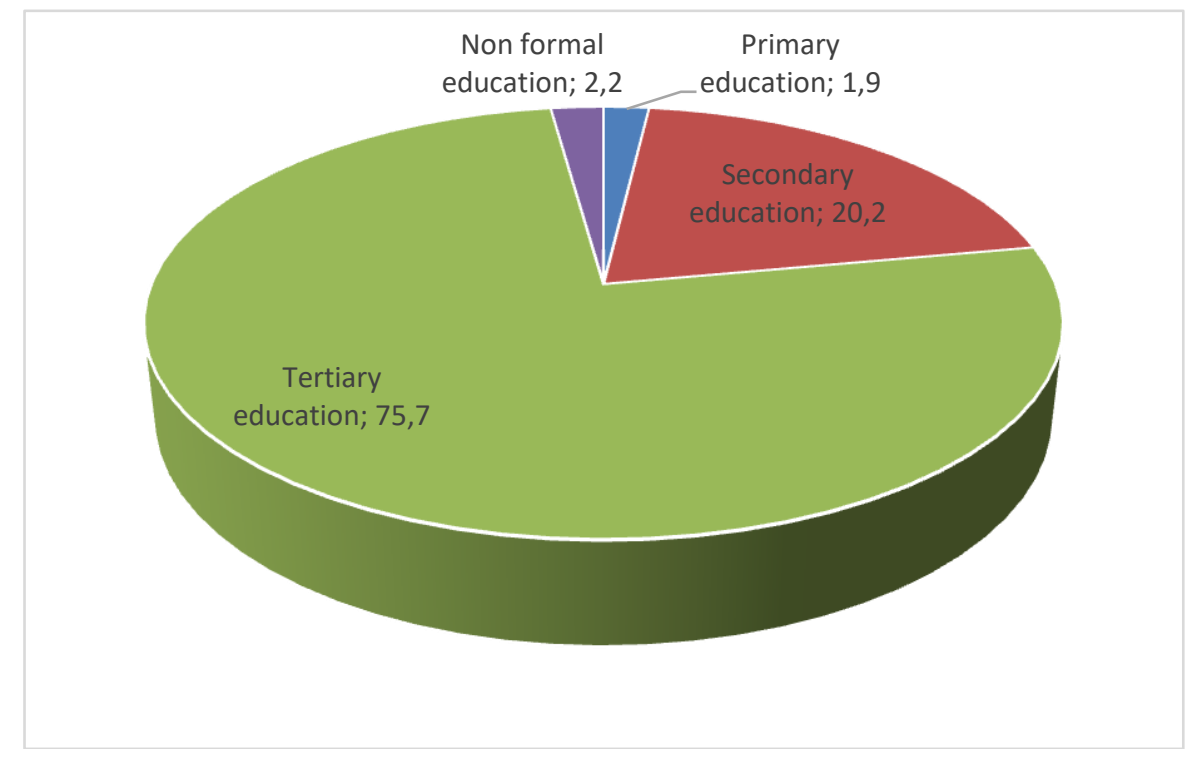

Figure 3 - Educational status distribution of agro-forestry farmers

The farming experience of agro-forestry farmers on Table 2 revealed that $53.6 \%$ of the farmers had 1 - 10 years of agro-forestry farming experience. $28.46 \%$ and $15.73 \%$ had $11-20$ and $21-30$ years of experience while only $2.25 \%$ had $41-50$ years of experience respectively. The average year of farming experience of the farmers was 11 years. This showed that most of the respondents had farmed for a reasonable number of years as would enable them to be abreast with agro-forestry technology.

The household size of agro-forestry farmers on Table 3 showed that majority $(33.71 \%)$ of the farmers had household sizes between $1-3$ persons. $26.22 \%, 24.34 \%$ and $11.24 \%$ had 4-6, 7-9 and 10-13 household size respectively. Only 4.49\% has household size between 1315 persons. The average household size was 5 persons with a minimum size of 1 person and a maximum of 14 persons. This indicates that household sizes among the agroforestry 
farmers were fairly small. The mean household size was equal to mean household size recorded by Ariyo et al (2020) and the national average household size of 5 persons (NBS, 2007). The size and composition of the household is an important variable in agricultural production because it suggests available labour force or pressure on land. Generally, a large household may imply high labour availability for different activities especially with high proportion of working adults and also more mouths to feed.

Table 2 - Farming Experience Distribution of Agro-forestry Farmers

\begin{tabular}{lll}
\hline Farming Experience & Frequency & Percent \\
\hline $1-10$ & 143 & 53.56 \\
$11-20$ & 76 & 28.46 \\
$21-30$ & 42 & 15.73 \\
$41-50$ & 6 & 2.25 \\
Total & 267 & 100.0 \\
Mean & 11 & \\
Min & 1 & \\
Max & 40 & \\
SD & 7.95 & \\
\hline
\end{tabular}

Table 3 - Household Size Distribution of Agro-forestry Farmers

\begin{tabular}{lll}
\hline Household size & Frequency & Percent \\
\hline $1-3$ & 90 & 33.71 \\
$4-6$ & 70 & 26.22 \\
$7-9$ & 65 & 24.34 \\
$10-12$ & 30 & 11.24 \\
$13-15$ & 12 & 4.49 \\
Total & 267 & 100.0 \\
Mean & 5 & \\
Min & 1 & \\
Max & 14 & \\
SD & 3.58 & \\
\hline
\end{tabular}

Farm size was measured by area of crops grown. It is the measure of availability of land for agricultural production. The result on Table 4 showed that majority $(73.41 \%)$ of the farmers had land holding of between $1-3$ hectares. The analysis further revealed that the mean farm sizes recorded during the survey was 2.8 implying that these farmers still fall within the range of smallholder farmers. Farm size is an indicator to the level or scale of production of an individual farmer. Under subsistence agriculture, farm size is expected to play a significant role in food availability because size of the land under cultivation will determine the size of food production. The finding of this study is consistent with Ekong (2003) who reported that most Nigerian farms are small-sized family farms in which family members contribute the required labour.

Table 4 - Farm Size Distribution of Agro-forestry Farmers

\begin{tabular}{lll}
\hline Farm Size & Frequency & Percent \\
\hline $1-3$ & 196 & 73.41 \\
$4-6$ & 53 & 19.85 \\
$7-10$ & 18 & 6.74 \\
Total & 267 & 100.0 \\
Mean & 2.8 & \\
Min & 1 & \\
Max & 10 & \\
SD & 2.18 & \\
\hline
\end{tabular}

The extension contact on Table 5 showed that $52.10 \%$ of the farmers had contact with the extension agent while $47.94 \%$ of the farmers do not have contact with the extension agent. Among the farmers that had contact, only very few $(4.32 \%)$ had the maximum contact of 6 times with minimum of 1 time contact and average of 3 times contact. The importance of extension contact is that frequent contacts between farmers and extension agents create 
more awareness and reduces difficulty in the adoption process. Contact with the extension can lead to improvement in food production as a result of information on improved agricultural technologies which would enhance greater productivity. Similarly, Cheryl and Michael (2000) found that the adoption of new technologies is often influenced by the frequency of the farmer's contact with extension agents. There are still significant challenges in providing extension and advisory services (EAS) in these areas. These range from insufficient funds for supporting public extension, poor resourcing, disorganized structures resulting in poor infrastructure for attracting businesses, limited involvement of rural farmers and populations in extension processes to the lack of appropriate strategies for effective research and adequate extension methods. Limited coverage of extension services across rural regions and challenges in adapting technology packages to community specific contexts have also been highlighted as critical issues in the delivery of EAS (IFPRI-World Bank 2010). Unfortunately, most of these innovations do not reach the farmers and this has been attributed to lack of effective agricultural information dissemination machinery. Extension services encompass the wide range of services provided by experts in the areas of agriculture, agribusiness, health and others and are designed to improve productivity and the overall wellbeing of rural populations.

Table 5 - Extension Contact Distribution of Agro-forestry Farmers

\begin{tabular}{lll}
\hline Extension Contact & Frequency & Percent \\
\hline No contact & 128 & 47.94 \\
Contact & 139 & 52.10 \\
Contact $(n=139)$ & & \\
Once & 24 & 17.27 \\
Twice & 60 & 43.17 \\
Thrice & 19 & 13.67 \\
Four times & 18 & 12.95 \\
Five times & 12 & 8.63 \\
Six times & 6 & 4.32 \\
Mean & 3 & \\
Min & 1 & \\
Max & 6 & \\
SD & 2.18 & \\
\hline
\end{tabular}

The membership of cooperative society on Table 6 revealed that high proportion $(51.69 \%)$ of agro-forestry farmers were members of cooperative association while $48.31 \%$ were non-member of cooperative association. The average number of years spent as a member was 5 years with a minimum of I years and maximum of 30 years in the study area. The implication of this result is that most of the farmers in the study area do enjoy the assumed benefits accrued to cooperative societies through pooling of resources together for a better expansion and effective management of resources. Membership of cooperatives societies has propensity to provision of credit facilities. People come together to pool their resources so as to meet individual needs that could not be resolved by individual limited financial capacity.

Table 6 - Cooperative Membership Distribution of Agro-forestry Farmers

\begin{tabular}{lll}
\hline Cooperative Membership & Frequency & Percent \\
\hline Non-Member & 129 & 48.31 \\
Members & 138 & 51.69 \\
$1-3$ & 54 & 39.13 \\
$4-6$ & 54 & 39.13 \\
$7-9$ & 6 & 4.35 \\
$10-12$ & 18 & 13.04 \\
$13-15$ & 6 & 4.35 \\
Total & 267 & 100.0 \\
Mean & 5 & \\
Min & 1 & \\
Max & 30 & \\
SD & 5.92 & \\
\hline
\end{tabular}


Channel of Communication Used in the Dissemination of Agro-Forestry Technologies was presented on Table 7. Extension is a system that helps in improving the knowledge of farmers to improve their farming methods and adopting a new practice with a view to increasing their standard of living. Through extension services, a new technique can be adopted for better production efficiency and income level to improve the living standard of the rural people. The ultimate aim of any agricultural extension programme is to help in improving the knowledge of farmers to improve their farming methods and adopting a new practice with a view to increasing their standard of living. This can be achieved by using right extension media. However, the various channel of communication used in the dissemination of agro-forestry technologies were indicated by the farmers and rated in order of magnitude. Table 7 showed that the use of radio $(79.78 \%)$ and television $(70.79 \%)$ were rated high by the famers among the channel of communication used in the dissemination of agro-forestry technology. Radio is a very important tool for rapid diffusion of information on agricultural innovations and also remains a powerful, cheapest mass medium that can reach large numbers of farmers. Radio also promotes dialogue and can also be used for training and transfer of agricultural technologies. It can be used to develop community cohesion and solidarity. Community involvement is fundamental for the successful use of radio with rural populations. Radio programmes are most effective when produced with audience participation, in local languages and with consideration for cultural traditions. Farmers can voice their concerns and speak about their aspirations with extension and other external partners such as national policy-makers and development planners through radio.

The result also revealed that extension agent (49.1\%) and visit $(42.7 \%)$ were moderately rated by the famers among the channel of communication used in the dissemination of agro-forestry technology. The plausible explanation to this finding is that access to extension services is critical in promoting adoption of modern agricultural production technologies because it can counter-balance the negative effect of lack of years of formal education in the overall decision to adopt some technologies. Agricultural information passed through an extension services therefore, reduces the level of uncertainty about a technology's performance that may change farmers' assessment to purely objective than subjective over time, thereby, facilitating adoption.

Newspaper (33.3\%), Group discussion (31.1\%), Cooperative, phone and campaign with equal value of $(29.2 \%)$ and demonstration $(22.5 \%)$ were rated low by the famers among the channel of communication used in the dissemination of agro-forestry technology in the study area. The rapid growth of mobile phones in developing countries over the past decade has introduced a new search technology that offers several advantages over other alternatives in terms of cost, geographic coverage and ease of use. Reducing the costs of disseminating technical information on agricultural innovations could increase the extension system's geographic scope and scale, and allow for contact between field agents and farmers at more crucial moments. This could, in turn, improve the quality (or value) of the information services provided.

Table 7 - Channel of Communication used in the Dissemination of Agro-forestry Technologies

\begin{tabular}{llll}
\hline Communication channel & Frequency* $^{*}$ & Percentage & Rate \\
\hline Radio & 213 & 79.78 & High \\
Television & 189 & 70.79 & High \\
Extension agent & 131 & 49.06 & Moderate \\
Visit & 114 & 42.70 & Moderate \\
Newspaper & 89 & 33.33 & Low \\
Group discussion & 84 & 31.46 & Low \\
Cooperative & 78 & 29.21 & Low \\
Phone & 78 & 29.21 & Low \\
Campaign & 78 & 29.21 & Low \\
Demonstration & 60 & 22.47 & Low \\
\hline
\end{tabular}

\footnotetext{
* Multiple responses.
} 
The major source of information to agroforestry farmers as presented on Table 8 was radio (81.65\%). The plausible explanation to this result is that radio cuts across the literacy barriers required in books, newspapers, journals, bulletins, pamphlets etc. Radio in essence often does not require higher educational qualification or back-ground to be effective. Even the pastoralists who are often physically inaccessible (to many other mass media, including electronic media) and who live in low population densities can be mobilized at the same time with radio anywhere without necessarily interfering with their daily activities at homes or in fields. Radio is a powerful communication tool (Chapman et al., 2003) that has also proved to be the most effective media in promoting agriculture and development in rural areas (Nakabugu, 2001). Radio and television are the most effective tools in communication for the support of development (Hussain, 1997). Radio is acknowledged as the most important medium for communicating with the rural populations of developing countries (FAO, 2001).Radio has many advantages, key among them are that it reaches a large audience, conveys messages or news very quickly, is particularly effective in rural areas and nonliterate cultures, is portable, it stimulates the imagination, and it carries authority (Norrish et al., 2001).

The Table also showed that (73.03\%) of the respondents got their agricultural innovation through Television. Nwachukwu and Odoemelam (2004) had found in their study that television viewing in developing countries is growing rapidly and has great scope for timely research and action. Extension agent $(59.93 \%)$ and visit $(57.72 \%)$ were regarded as moderately source of information by agroforestry farmers. This could stem from the fact that the number of qualified agricultural extension workers is grossly inadequate to make meaningful impact on the economy. In some remote areas, such extension services are lacking completely and farmers are left to use their traditional knowledge to improve their productivity. This supports the view given by the IFAD (2005) that the extension delivery system is inefficient, and as a result is not effective in the delivery of extension services in rural areas.

Campaign (13.48\%), demonstration (11.24\%), Group discussion and phone $(6.74 \%)$, Newspaper and Cooperative (4.49\% each) were regarded as low source of information by agroforestry farmers. People in the rural areas are still hesitant to use the advance technology that is available to them. Rural community seems reluctant to use the advance technology such as internet to receive agriculture information. This result is in line with Abu Hassan et al. (2009) who have reported few reasons why people are reluctant to use advance technology such as internet and among the reasons are people do not know the benefits of the advance technology, do not have skills or expertise in using the advance technology, lack of time spent on ICT and difficulties in using ICT.

Table 8 - Distribution of Sources of Information to Agro-forestry Farmers

\begin{tabular}{llll}
\hline Sources of awareness & Frequency* & Percentage & Decision \\
\hline Radio & 218 & 81.65 & High \\
Television & 195 & 73.03 & High \\
Extension agent & 160 & 59.93 & Moderate \\
Visit & 156 & 57.72 & Moderate \\
Campaign & 36 & 13.48 & Low \\
Demonstration & 30 & 11.24 & Low \\
Group discussion & 18 & 6.74 & Low \\
Phone & 18 & 6.74 & Low \\
Newspaper & 12 & 4.49 & Low \\
Cooperative & 12 & 4.49 & Low \\
\hline
\end{tabular}

* Multiple responses.

The level of awareness of various agro-forestry technologies will determine the extent to which the farmers will practice them. Agro-forestry as a system of land use where wood perennial (trees or shrubs) are deliberately planted with annual crops at the same time animal are reared on the same piece of land with the aim of obtaining greater output (Kabir, 2011). According to NAC (2015) Agro-forestry or agro-silviculture is a land use management 
system in which trees or shrubs are grown around or among crops or pasture land. It combines shrubs and trees in agricultural and forestry technologies to create more diverse, productive, profitable, healthy, ecologically sound, and sustainable land use systems. The level of awareness of different components of agroforestry technology by the farmers was accessed with 5-point Likert-scale. The farmer's responses were categorized into highly aware, aware, undecided, unaware and highly unaware. The responses were gathered, analyzed and presented on Table 9 . The table showed that multistory system $(\overline{\mathcal{H}}=3.78)$, shelter belts and windbreak system $(\overline{\mathcal{H}}=3.69)$, alley cropping system $(\overline{\mathcal{X}}=3.66)$, fodder bank system $(\overline{\mathcal{X}}=3.81)$, live fence and fodder hedge row system $(\overline{\mathcal{K}}=3.60)$, tree and shrubs on pasture system $(\overline{\mathcal{H}}=3.91)$, tree and livestock crop mixture $(\overline{\mathcal{X}}=3.73)$ and integrated production system $(\overline{\mathcal{X}}=3.90)$ were aware by the farmers as among agroforestry technologies which enables the farmer to achieve a better, ecological beneficial and biodiversity supportive system of agricultural production by planting crops, trees, shrubs and pasture. However, the agroforestry farmers were undecided whether bush fallow system $(\overline{\mathcal{X}}=3.45)$ and taungya system $(\overline{\mathcal{H}}=3.48)$ are part of agro-forestry technology.

Table 9 - Level of Awareness of various Agro-forestry Technologies among Farmers

\begin{tabular}{lllllllll}
\hline Agro-forestry technologies* $^{*}$ & HA & A & U & UA & HUA & MEAN & SD & Decision \\
\hline Bush fallow system & 102 & 59 & 28 & 12 & 66 & 3.45 & 1.61 & Undecided \\
Multi-story system & 77 & 125 & 17 & 24 & 24 & 3.78 & 1.21 & Aware \\
Shelter belts and windbreak system & 90 & 89 & 34 & 24 & 30 & 3.69 & 1.32 & Aware \\
Alley cropping system & 76 & 107 & 24 & 36 & 24 & 3.66 & 1.27 & Aware \\
Taungya system & 65 & 83 & 59 & 36 & 24 & 3.48 & 1.25 & Undecided \\
Fodder bank system & 88 & 101 & 30 & 36 & 12 & 3.81 & 1.16 & Aware \\
Live fence and fodder hedge row system & 66 & 106 & 35 & 42 & 18 & 3.60 & 1.21 & Aware \\
Tree and shrubs on pasture system & 83 & 118 & 36 & 18 & 12 & 3.91 & 1.06 & Aware \\
Tree and livestock crop mixture & 72 & 111 & 36 & 36 & 12 & 3.73 & 1.13 & Aware \\
Integrated production system & 75 & 138 & 12 & 36 & 6 & 3.90 & 1.03 & Aware \\
\hline
\end{tabular}

* Multiple responses. $H A=$ highly aware, $A=$ aware, $U=$ undecided, $U A=$ unaware, $H U A=$ highly unaware and $S D=$ standard deviation.

Most Preferred Extension Communication Channels by the agro-forestry Farmers presented on Table 10 revealed that group discussion (79.78\%) and visit (70.79\%) were the most preferred extension communication channels. Farmer's inclination towards group discussion implies that they learn best when they are made participants of learning process in a democratic and friendly atmosphere. Further, through visit (individual contact) skills is better acquired and are generally practical-oriented and motivate farmers to take initiative by bringing a desirable change in his attitude. The main function of these methods is to make farmers aware of specific practices and make him realize that practice will result into better outcome. The principal focus of the visit (individual) method is to improve co-ordination and interaction with farming community to simulate the adoption of technology by enhancing better understanding.

Table 10 - Distribution of most Preferred Extension Communication Channel by the Agro-forestry farmers

\begin{tabular}{llll}
\hline Communication channels & Frequency* $^{*}$ & Percentage & Decision \\
\hline Group discussion & 213 & 79.78 & Highly preferred \\
Visit & 189 & 70.79 & Highly preferred \\
Extension agent & 177 & 66.29 & Preferred \\
Radio & 108 & 40.45 & moderately preferred \\
Television & 108 & 40.45 & moderately preferred \\
Campaign & 102 & 38.20 & Least preferred \\
Demonstration & 102 & 38.20 & Least preferred \\
Cooperative & 96 & 35.96 & Least preferred \\
Newspaper & 84 & 31.46 & Least preferred \\
Phone & 72 & 26.97 & Not preferred \\
\hline
\end{tabular}

\footnotetext{
* Multiple responses.
} 
Extension agent (66.29\%) was preferred while radio $(40.45 \%)$ and television $(40.45 \%)$ were moderately preferred. The moderately preference for radio and television could stem from the economic situation (affordability) of the study area. The poor outcome of campaign, demonstration, cooperative, newspaper and phone in its less preference regarding information dissemination is found among the low literate farmers of the study area and miserable economic plight of masses to get benefit from mass media.

The problems to effective extension communication channel used in dissemination of agroforestry information were ranked according to their magnitude as stated by the farmers (Table 11). The problem of inadequate extension agent was ranked first among the constraint of extension communication channel, accounting for about $80.15 \%$. This is connected to the fact that the ratio of extension agents to farm family is 1:5,128 in Ekiti State (EADP, 2016). This is grossly too small for a meaningful development. The present ratio of extension worker to farmers is inadequate for effective agricultural information transfer and diffusion.

Incompetency of extension agents was ranked as the second constraint facing agroforestry farmers in the study area; the result showed that $62.55 \%$ of the farmers indicated this as a constraint; this may likely hamper effectiveness of extension communication channel provided by the agents through their organization to the end-users. Inadequate effort, energy or enthusiasm on part of extension agents in the dissemination of extension services to agroforestry farmers may likely decrease the effectiveness of the services provided and consequently translate to low output of productivity. While respondents poor attendance of meeting $(52.43 \%)$ was ranked third in order of magnitude.

Lack of skills, knowledge, attitude and ability to deliver appropriate agricultural information (51.69\%) was ranked fourth as one of major constraint and it is apparent that without further training, the extension staffs presently delivering extension services to smallholder farmers and rural communities cannot give information on recent improved farm practices and innovations which they themselves are not aware of. They lack the skills, knowledge, attitude and ability to deliver appropriate agricultural information and messages that farmers will use to enhance their production, productivity and other agricultural practices and activities.

Lack of cooperation among respondents was ranked fifth with $50.56 \%$ as indicated in the result, this could mean there are probably some information some farmers are privy to which they would not want to share with their fellow farmers due to advantage the information may contain in relation to their crop productivity. Inadequacy of existing extension programs $(33.33 \%)$ was ranked sixth as one of major constraint. Some of these programs are conceived without well thought out plans and are prepared in a hurry without the farmers whose attitudes are to be changed making any input. Such agricultural packages can neither sustain the farmers' interest nor effect the desired attitudinal change. Farmers' interests are disregarded even more as most of the agricultural innovations are written and broadcast in English instead of the local language.

Inappropriate use of communication channel (25.84\%) was rank seventh. One of the obvious in the use of the broadcasting media in Nigeria is poor reception quality and the area covered. The messages carried are not tailored to the information needs of rural populations. Even when the information is relevant, it is seldom aired at the proper time and so does not get to the targeted audience.

Table 11 - Distribution of Constraints to Effective Extension Communication Channels in Disseminating Agro forestry Technologies to Farmers

\begin{tabular}{llll}
\hline Constraints & Frequency $^{*}$ & Percentage & Rank \\
\hline Inadequate extension staff & 214 & 80.15 & $1^{\text {st }}$ \\
Incompetency of extension agents & 167 & 62.55 & $2^{\text {nd }}$ \\
Respondents poor attendance at meeting & 140 & 52.43 & $3^{\text {rd }}$ \\
Lack of skill and knowledge to deliver agro-forestry information & 138 & 51.69 & $4^{\text {th }}$ \\
Lack of cooperation among respondents & 135 & 50.56 & $5^{\text {th }}$ \\
Inadequacy of existing extension programs. & 89 & 33.33 & $6^{\text {th }}$ \\
Inappropriate use of communication channel & 69 & 25.84 & $7^{\text {th }}$ \\
\hline
\end{tabular}

${ }^{*}$ Multiple responses. 


\section{CONCLUSION}

The study concludes that the majority of the respondents are male, having average age of 38 years with minimum and maximum age of 16 and 64 years. They are married with average household size of 5 , average farm size 2.8 ha and average farming experience of 11 years respectively. Radio and television are the sources of information to agro-forestry farmers and channels of disseminating agro-forestry technologies. The farmers are aware of different agro-forestry components such as multi-story system, shelter belts and windbreak system, alley cropping system, fodder bank system, live fence and fodder hedge row system, tree and shrubs on pasture system, tree and livestock crop mixture and integrated production system. It can be further concluded that group discussion and visit were the most preferred extension communication channels. The major constraint to effective extension communication channels in disseminating agro-forestry technologies was inadequate extension agent.

\section{RECOMMENDATIONS}

Farmers have their own way of learning and receiving information which is best suited for them. The study therefore recommends the use of group discussion and visit as the most appropriate communication channels to the agro-forestry farmers in the study area. The timing of group activities should be negotiated and agreed upon by the farmers to enhance good attendance at such meeting. The study further recommended that the ratio of extension agents to farmers should be improved and more extension agents should be made available to farmers. This will enhance the dissemination of information and increase awareness about agro-forestry technologies. The extension agents should be properly trained to acquire skills and knowledge to deliver agro-forestry innovations. This will improve effective and efficient agro-forestry delivery.

\section{REFERENCES}

1. Abu Hassan, M. S., Hassan Shaffril, H. A. M and Jeffrey Lawrence, D. S. (2009). Problems and obstacles in using Information and Communication Technology (ICT) among Malaysian Agro-Based Entrepreneurs. Eur. J. Sci. Res., 36: 93-101.

2. Adamu, B. (2005). Daily Trust Newspapers, Kaduna, Nigeria, pp. 20-22.

3. Adeola, A. O. (2015). Principles and practice of Agroforestry.Akure: Yempet Publishers. Pp136.

4. Age, A. I., Obinne, C. P. O., and Demenongu, T. S. (2012). Communication for Sustainable Rural and Agricultural Development in Benue State, Nigeria. Sustainable Agriculture Research journal, 1(1), 118.

5. Ajayi, O. J. and Gunn, E. E. (2009). The Role of Communication in Dissemination of Improved Agricultural Technology in Bosso Local Government Area of Niger, Nigerian Journal of Agricultural Extension, 13 (1): 66-72.

6. Ariyo, O. C., Usman, M. B., Olorukooba, M. M., Olagunju, O. E., Oni, O. B., Suleiman, R., Adetunji, A. J., \& Ariyo, M. O. (2020). Economics of Yam Production in Gboyin Local Government Area of Ekiti State, Nigeria. Journal of Experimental Agriculture International, 42(4), 99-110. https://doi.org/10.9734/jeai/2020/v42i430504, Article no. JEAI.57140, ISSN: 2457-0591.

7. Ariyo, O. C, Ariyo, M. O, Okelola, O. E, Aasa, O. S, Awotide, O. G, Aaron, A. J, and Oni, O. B .(2013). Assessment of the Role of Mass Media in the Dissemination of Agricultural Technologies among Farmers in Kaduna North Local Government Area of Kaduna State, Nigeria. Journal of Biology, Agriculture and Healthcare, 3(6):19-28.

8. Bello, K. (2016). Evaluation of factors influencing the utilization of extension services provided by Adamawa Agricultural Development and Investment Limited to Maize farmers in Adamawa, State, Nigeria, An unpublished PhD thesis submitted to Department of Agricultural Economics and Rural Sociology, Ahmadu Bello University, Zaria, pp. 187. 
9. Chapman, R., Blench, R., Kranjac-Berisavljevic', G. and Zakariah, A.B.T. (2003). Rural radio in an agriculture extension: The example of vernacular radio programs on soil and water conservation in N.Ghana. Agricultural Research and Extension Network(AgREN). Network Paper No. 127.

10. Cheryl, R. D. and Michael, L. M. (2000). How does gender affect the adoption of agricultural innovations? The case of improved maize technology in Ghana. Women agriculture and rural development. Findings of FAO study in Africa. Retrieved on 18/6/2002 from http//www. Anpen.2002.rat/htm webpage 1.

11. Dahunsi, M. O. (2012). Determinants of participation in Taungya Ago forestry Practice among Farmers in Ekiti state, Nigeria. Unpublished MSc Thesis Department of Agricultural Economics and Rural Sociology, Ahmadu Bello University, Zaria, pp. 148.

12. Ekiti State Agricultural Development Programme Ikole Ekiti (EADP, 2016). Agric Extension Sub - Programme Annual Report for the year 2016. Presented at the South West Zonal Research Extension Farmer Input Linkage System (Refils), Workshop Holding At Institute of Agricultural Research and Training (IAR\&T) Moor Plantation, Ibadan, Oyo State, pp.1-16.

13. Ekong, E. E. (2003). Rural Sociology: An introduction and analysis of rural Nigeria, Uyo: Dove Educational Publication, Nigeria, pp. 250.

14. Ewuola, S. O., Ogunsumi, L. O., and Augustu, E. O. (2010). Assessment of Extension Media Use Among Youth Farmers In Oyo and Ondo States, Nigeria. American Journal of Social and Management Sciences, 1(2): 181-185.

15. Faleyimu, O. I, Agbeja, B. O, Akinyemi, O. (2013). State of forest regeneration in Southwest Nigeria. African Journal of Agricultural Research, 2013; 8 (26): 3381- 3383. DOI: 10.5897/AJAR09.035. ISSN 1991-637X C2013 Academic Journals. http://www.academicjournals.org/AJAR.

16. FAO. (2001). Knowledge and information for food security in Africa from traditional media to the Internet. Communication for Development Group, Sustainable Development Department. Rome: FAO.

17. Hussain, M. (1997). Mass Media. In: Memon, R.A. and Basir, E. (eds.), Extension Methods, pp: 208-61. Islamabad, Pakistan:National Book Foundation.

18. IFAD (International Fund for Agricultural Development) (2005). Promoting Market Access for the rural poor in order to achieve the millennium development goals. Rome: IFAD.

19. IFPRI-World Bank. (2010). Gender and governance in rural services: Insights from India, Ghana, and Ethiopia. Agriculture and Rural Development. Washington, DC, USA: The World Bank.

20. Ivan, S. A., Peter, F. O., Richard, M. M., Anthony, O. E., Franklin, S. M. and Elizabeth, N. (2012). Analysis of Communication and Dissemination Channels Influencing the Adoption of Integrated Soil Fertility Management in Western Kenya, Journal of Agricultural Education and Extension, 18 (1): 71- 86.

21. Jamilah, O., M. Azril, S. H., Jegak, U., Asiah, M., and Azman, A.N. (2010). Can quality of work life affect work performance among government agriculture extension officers? A case from Malaysia. Journal of Social Science, 6: 64-73.

22. Kabir, U. L. (2011). Analysis of Agro-Forestry Farmers (Tree-Planning) in Giwa Local Government Area, Kaduna State.Unpublished M.Sc. Thesis Department of Agricultural Economics and Rural Sociology, Ahamadu Bello University, Zaria.

23. Lawal, W. L. and Idega, E. O. (2004). Analysis of Fish Marketing in Benue State. A Paper Presented at 2004 Annual Conference of the Association of Agricultural Economics (NAAE) Held at A.B.U Zaria, November 3, 2004.Misra D.C. (1997). Monitoring Extension Programme and Resources References Manuel $\left(2^{\text {nd }}\right)$. Pp.151-160.

24. Minot N. and Ngigi, M. (2006). Are horticultural exports a replicable success story? Evidence from Kenya and Côte d'Ivoire. Environment and Production Technology Division Discussion Paper No. 120/Markets, Trade, and Institutions Division Discussion Paper No. 73. Washington, DC: International Food Policy Research Institute, 2006. 
25. Nakabugu, S. B. (2001). The Role of Rural Radio in Agricultural and Rural Development Translating Agricultural Research Information into Messages for Farm Audiences. Programme of the Workshop in Uganda, 19 February 2001.

26. National Agro-Forestry Centre (2015).NAC United States department of Agriculture. Report of Findings in the 2014 Agricultural Avt. Inside Agro-Forestry magazine USDA. From Http://www.Usda.gov/agroforestry.htm. Accessed on 12th September, 2015.

27. NBS. (2007). National Bureau of Statistic Abuja Nigeria; 2007.

28. Norrish, P., Lloyd Morgan, K. and Myers, M. (2001) Improved Communication Strategies for Renewable Natural Resource Research Outputs. Socioeconomic Methodologies for Natural Resources Research. Best Practice Guidelines. Chatham, UK: Natural Resources Institute.

29. Nwachukwu I and Odoemelam, L. C (2004). Effectiveness of television farm broadcast in the transfer of technology to farmers in Abia State, A paper presented at the 9th Annual Conference of AESON, lle-Ife, Nigeria, p. 3.

30. Nwaiwu J.C., Ihentuge P.C., Iwuagu E.N. and Gogo V. C. (2018). Assessment of Information and Communication Technologies (ICTs) Used By Extension Agents in Dissemination of Agricultural Innovation in Owerri Agricultural Zone of Imo State, Nigeria. International Journal of Innovative Food, Nutrition \&Sustainable Agriculture 6(4):17-24.

31. Olowu, T.A, Oyedokun, O.A and Oladele, O.I (2001). Effective Communication Techniques. A handbook of Agricultural Extension Services and Communication pp.3543. Codat publications, Ibadan, Nigeria.

32. Ogunremi, J. B. (2013). Assessment of Extension Agents' Use of Communication Methods and its Impact on Aquaculture Linkage Activities in Lagos State, Nigeria. Journal of Agriculture and Social Research, 13 (1): 15-20.

33. Robinson, K., Elliott, S. J., Driedger, S. M., Eyles, J., O’Loughlin, J., Riley, B., Cameron, R. and Harvey, D. (2005) Using Linking Systems to Build Capacity and Enhance Dissemination in Heart Health Promotion: A Canadian Multiple-case Study. Health Education Research: Theory \& Practice, 20(5): 499-513.

34. Rees, D., Momanyi, M., Wekundah, J., Ndungu, F., Odondi, J., Oyure, A. O., Andima, D., Kamau, M., Ndubi, J., Musembi, F., Mwaura, L. and Joldersma, R. (2000). Agricultural Knowledge and Information Systems in Kenya. Implications for Technology Dissemination and Development. Network Paper No. 107. London: Agricultural Research \& Extension Network (AgREN).

35. Rogers, E. (2003). Diffusion of Innovations. $5^{\text {th }}$ Edition New York: The Free Press.

36. Sinkaiye, T. (2005). Agricultural Extension Participatory Methodologies and Approaches in Agricultural Extension in Nigeria. AESON, Ilorin. Pp. 220-233. 